\title{
Serum IGF-1 levels as a clinical tool for optimizing orthodontic treatment timing
}

\author{
Sapna Jain ${ }^{1 *}$, Sandhya Jain ${ }^{1}$, Anuradha Deoskar ${ }^{1}$ and VS Sai Prasad ${ }^{2}$
}

\begin{abstract}
Background: The study aims to associate serum insulin-like growth factor-1 (IGF-1) levels with cervical maturation stages (CS) 3, 4, and 5 on lateral cephalogram in male subjects and to find out peak serum IGF-1 levels among these three stages.

Methods: The study was conducted on 45 male subjects who were at skeletal maturation stage CS-3, CS-4, and CS-5. Subjects were selected using simple random sampling technique. Serum IGF-1 levels were estimated from blood samples using chemiluminescence immunoassay (CLIA) method. CS was evaluated using a six-stage method of evaluating the cervical vertebrae. Mean IGF-1 levels between the stages were compared by analysis of variance (ANOVA) test.
\end{abstract}

Results: One-way ANOVA showed highly significant differences between all cervical stages with $p$ value $<0.01$, but post hoc Tukey test showed highly significant differences between CS-4 and CS-5 with $p$ value 0.006 . Serum IGF-1 levels showed good association with skeletal age in male subjects; $53.3 \%$ of subjects at CS-3, 66.7\% subjects at CS-4, and $6.7 \%$ subjects at CS-5 showed IGF-1 levels in peak range.

Conclusions: Serum IGF levels can be used as an additional tool to optimize orthodontic treatment timing.

\section{Background}

The assessment of growth potential is essential because of individual variations in timing, duration, and velocity of growth. The classic method of assessing skeletal maturity is by the use of a hand-wrist radiograph. Assessing the degree of cervical vertebral maturation on lateral cephalometric radiograph [1-8] and recording MP3 stages $[9,10]$ on periapical $\mathrm{X}$-ray films are also used to identify peak mandibular bone growth and skeletal maturity. Radiographic methods, which are highly subjective techniques, involve radiation exposure. More recently, the use of some additional methods with cervical maturation method for the assessment of biologic maturity is proposed $[11,12]$. If the shape of the cervical vertebrae does not show the exact stage, then additional method can be of use to predict the maturation stage accurately.

Gingival crevicular fluid alkaline phosphatase level may be used as a noninvasive clinical biomarker for the identification of pubertal growth spurt but only in

\footnotetext{
* Correspondence: sapnajainorthogdcindore@gmail.com

${ }^{1}$ Department of Orthodontics \& Dentofacial Orthopedics, Government College of Dentistry, Opp. Maharaja Yashwantrao Hospital, Indore, India Full list of author information is available at the end of the article
}

periodontally healthy subjects [13]. Insulin-like growth factor-1 (IGF-1) is one of the main mediators of the actions of growth hormone in promoting muscular and skeletal growth [14-16]. Parallel to the increase in growth hormone secretion at puberty, circulating IGF-1 also increases [17]. A study has shown that the condyle is more responsive and sensitive to IGF-1 than the femoral head [18]. Mean IGF-1 blood spot levels in the late pubertal stages have been observed to be higher than in the prepubertal, early pubertal, and postpubertal stages [19]. IGF-1 levels were highest at the hand-wrist stages that are previously associated with the greatest amount of mandibular growth [20].

Reference ranges of serum IGF-1 levels in male and female subjects have been established separately according to chronological age [21]. Age-related increase occurs in serum IGF-1 levels during the prepubertal and early pubertal stages and a decrease in late puberty, but chronological age is not a reliable indicator for skeletal maturity [22-24].

Since IGF-1 levels vary according to age and sex [21], separate studies are needed for male and female subjects. The pubertal peak occurs approximately 2 years earlier 
in girls than in boys [25]. Serum IGF-1 level is a reliable maturation factor for the assessment of skeletal maturity [26]. Since serum IGF-1 quantitatively assesses growth, the intensity of growth can therefore be estimated which would further help in assessing the exact timing of treatment.

The purpose of this study was to associate serum IGF1 levels with cervical vertebrae maturation stages so as to find out whether IGF-1 levels can be used as a clinical tool or not. The objective was to find out peak serum IGF-1 levels corresponding to cervical vertebrae maturation stages (CS) 3,4 , and 5 in circumpubertal male subjects.

\section{Methods}

The sample used in the study consisted of 45 male subjects, who were at CS-3, CS-4, and CS-5, selected from the patients coming to the Department of Orthodontics and Dentofacial Orthopedics and Department of Pedodontics at our institute by simple random technique. Patients meeting the set selection criteria were selected from the daily patient register until a sample size of 15 was reached in each group to eliminate both deliberate and unconscious bias. Inclusion criteria were male subjects who were at CS-3, CS-4, and CS-5 based on information about birth date and their good health status. Exclusion criteria were subjects suffering from any serious illness; growth abnormality, e.g., craniofacial syndromes, rickets, medical syndromes, bone disease, and bone deformities; bleeding disorders, or history of any serious trauma or injury to the face. The research protocol was approved by the ethical committee of the Government College of Dentistry, Indore, India. Parental/ patient's informed consent was taken for enrolment of each subject in the study.

Lateral cephalograms were taken in natural head position within an hour of blood collection. All the radiographs were exposed at $80 \mathrm{kVp}, 9 \mathrm{~mA}$ for $1.25 \mathrm{~s}$. The six-stage cervical staging technique by Baccetti et al. [6] was used to determine the stages of cervical vertebrae maturation. The observer was blinded about each patient's age and IGF-1 levels. A double determination was carried out on all the 45 individual's radiographs by the same operator at a second session after 15 days. These tracings were analyzed separately, and two sets of readings were obtained for statistical evaluation.

Blood samples were collected between OPD hours of 9:00 a.m. and 12:00 p.m., and serum was separated from the blood samples, labelled with patient's name, properly sealed, stored in a thermocol box with ice pack (kept at $2^{\circ} \mathrm{C}$ to $8^{\circ} \mathrm{C}$ ), and sent to the laboratory for chemiluminescence immunoassay for determination of IGF-1 levels by a fully automated, two-site chemiluminescent immunoassay (Siemens Immunolite 2000 (Siemens, Munich, Germany) immunoassay machine at Metropolis Laboratories). Each patient's height and weight were measured as they might affect serum IGF-1 levels.

\section{Statistical analysis}

The Pearson correlation was used to measure intraexaminer reliability. The mean Pearson correlation for all variable was 0.932 , and it ranged from 0.801 to 0.988 , which implies a highly significant correlation between the observations $(p=<0.01)$.

Analysis of variance (ANOVA) and post hoc tests were used to compare mean IGF-1 levels and cervical vertebral maturation stages. All statistical analyses were performed using SPSS18 for Windows software (version 18.0; SPSS, Chicago, IL, USA). The significance level was set at $p<0.01$. Student's $t$ test was applied to show significant differences between the orthodontic classes (CS-5) and orthopedic groups (CS-3 and CS-4).

\section{Results}

Differences were observed between the cervical stages $(p<0.01)$ when analyzed by one-way ANOVA (Table 1$)$; highly significant differences were found between CS-4 and CS-5 $(p=0.006)$, whereas nonsignificant differences were found between CS-3 and CS-4, and between CS-3 and CS- 5 by post hoc Tukey test (Table 2).

Peak IGF-1 level was found in CS-4. In the CS-5 group, IGF-1 level was consistently on the lower hub in all three maturity groups, suggesting the fact that most patients attain their maximum growth by the time of CS-5 (Table 3).

Table 4 shows the mean IGF-1 level with respect to orthodontic and orthopedic groups. By Student's $t$ test, highly significant differences were observed between the classes and serum IGF-1 level with a $p$ value of 0.006 .

Table 1 Descriptive IGF-1 (ng/ml) statistics for each cervical stage

\begin{tabular}{|c|c|c|c|c|c|c|c|}
\hline \multirow[t]{2}{*}{ Cervical stage } & \multirow[t]{2}{*}{ Subjects } & \multirow[t]{2}{*}{ Mean IGF-1 (ng/ml) } & \multirow[t]{2}{*}{ SD } & \multicolumn{2}{|c|}{$95 \%$ confidence interval for mean } & \multirow[t]{2}{*}{ Minimum } & \multirow[t]{2}{*}{ Maximum } \\
\hline & & & & Lower bound & Upper bound & & \\
\hline$\overline{C S}-3$ & 15 & 318 & 17.4 & 283 & 353 & 171 & 433 \\
\hline CS-4 & 15 & 352 & 17.7 & 317 & 387 & 252 & 525 \\
\hline CS-5 & 15 & 279 & 10.8 & 257 & 301 & 206 & 372 \\
\hline
\end{tabular}

ANOVA: $p$ value $=0.008$, highly significant. SD, standard deviation. 


\begin{tabular}{|c|c|c|c|c|}
\hline Group (mean) & Compared group & Mean difference & SE & $p$ value \\
\hline \multirow[t]{2}{*}{ CS-3 (318.13) } & CS-4 (352.40) & -34.27 & 22.05 & 0.277 \\
\hline & & & & NS \\
\hline \multirow[t]{2}{*}{ CS-4 (352.40) } & CS-5 (279.67) & 72.73 & 22.05 & 0.006 \\
\hline & & & & Sig \\
\hline \multirow[t]{2}{*}{ CS-5 (279.67) } & CS-3 (318.13) & -38.47 & 22.05 & 0.201 \\
\hline & & & & NS \\
\hline
\end{tabular}

NS, nonsignificant $(p>0.05)$; Sig, significant $(p<0.05)$; SE, standard error.

The scatter curve (Figure 1) showed that IGF-1 level increased with increasing age at CS-3 and decreased with age at CS-4 and CS-5. Serum IGF-1 level increased up to 15 years of age and decreased thereafter.

\section{Discussion}

The present study was done to evaluate serum IGF-1 levels in CS-3, CS-4, and CS-5 (circumpubertal growth period) because these stages are clinically more relevant stages with the orthodontic speciality. The cervical staging determination method used which was given by Baccetti et al. [6] is considered to be a better method in comparison to other methods [27].

In the present study, mean peak serum IGF-1 level in male subjects at CS-4 (352 ng/ml) was observed, in contrast to a similar study where mean peak IGF-1 level at CS-3 $(397 \mathrm{ng} / \mathrm{ml})$ was noticed in female subjects [28]. A possible explanation for the difference observed in stages where peak in IGF-1 levels between the two studies is observed could be related to gender difference since the timing of puberty differs in male and female subjects [1]. This is in accordance with the statement by Proffit [29]: "Girls mature earlier, and finish their growth much sooner. The differences arise because in males slow but steady growth occurs before the growth spurt." It was also observed that $53.3 \%$ (8 out of 15 ) of the subjects at CS-3, $66.7 \%$ of the subjects (10 out of 15 ) at CS-4, and $6.7 \%$ of the subjects ( 1 out of 15 ) at CS-5 showed IGF-1 levels in peak range.

The scatter curve showed that serum IGF-1 levels increased with age in CS-3 and decreased with age in CS-4 and CS-5, which means that the peak in serum IGF-1 may occur at the fag end of CS-3 and at the beginning of CS-4. The observed peak IGF-1 levels at CS-3 and CS-4 in the present study coincide with cervical stages with peak mandibular growth, observed by Baccetti et al. [6] in 2005.

The mean serum IGF-1 level in the CS-4 group is $352 \pm 17.7 \mathrm{ng} / \mathrm{ml}$ with a mean age of 15.9 years, which is in accordance with the study by Brabant et al. [21], in which the highest mean IGF-1 was $382 \mathrm{ng} / \mathrm{ml}$ for males which occurred at the age of 15 to 16 years. Studies $[21,25]$ have attempted to establish a reference range of serum IGF-1 levels according to chronological age in male and female subjects separately, but several studies have shown that chronological age is a poor predictor of the pubertal growth spurt [22-24].

The present study showed the range of serum IGF-1 levels as 171 to $433 \mathrm{ng} / \mathrm{ml}$ for CS-3, 252 to $525 \mathrm{ng} / \mathrm{ml}$ for CS-4, and 206 to $372 \mathrm{ng} / \mathrm{ml}$ for CS-5. The clinical usefulness of the study is limited because of overlapping levels of serum IGF-1 in all three cervical stages, possibly due to the relatively small sample size, cross-sectional design of the study, different body types (aesthetic/athletic/ plethoric), and different maturational groups (advanced/ average/delayed).

In order to use IGF-1 levels as a diagnostic tool in clinical orthopedic case selection and for establishing a cutoff reference value of IGF-1 for different types of treatments, the subjects in CS-3, CS-4, and CS-5 were divided into two groups. Since post hoc analysis revealed no statistical difference in CS-3 and CS-4, therefore, the subjects at CS-3 and CS-4 were combined and considered as class 1 (orthopedic treatment type) in which orthopedic corrections are possible, and subjects at CS-5 were considered as class-2 (orthodontic treatment type). After statistical analysis of these two treatment classes, new upper and lower bound limits of IGF-1 levels were obtained which were 310 and $360 \mathrm{ng} / \mathrm{ml}$, respectively, for orthopedic treatment class and 258 and $302 \mathrm{ng} / \mathrm{ml}$ for orthodontic treatment class. Based on these upper and lower bound values, a cutoff value of serum IGF-1 levels for various treatment options was obtained as $310 \mathrm{ng} / \mathrm{ml}$. This means that in patients with serum IGF-1 levels $>310 \mathrm{ng} / \mathrm{ml}$, orthopedic treatment may be considered.

To gain additional information about maturational status of growth, the sample was further divided into three groups (advance, average, and delayed maturer) in each cervical stage on the basis of lower and upper bound limits of age. Samples below the lower bound limit of age were considered as advance maturers, those within the lower and upper bound limit of age were average maturers, whereas those above the upper bound limit of age were considered as delayed maturers.

In CS-3, much higher IGF-1 levels were found in delayed maturers (subjects above the upper bound limit of age). This finding can be useful in clinical orthodontic practice as in delayed type of maturers at CS-3 treatment should be started without delay. In delayed maturers at CS-3, mean height and weight also increased, which was possibly the explanation for increased IGF-1 
Table 3 Mean serum IGF-1, mean height, and mean weight with respect to various CS in different types of maturers

\begin{tabular}{|c|c|c|c|c|c|c|c|c|c|c|c|c|}
\hline \multirow{2}{*}{$\begin{array}{l}\text { Cervical } \\
\text { stage }\end{array}$} & \multirow{2}{*}{$\begin{array}{l}\text { Mean age } \\
\text { (years) }\end{array}$} & \multicolumn{2}{|c|}{ 95\% confidence interval (years) } & \multicolumn{3}{|c|}{ Advance maturer } & \multicolumn{3}{|c|}{ Average maturer } & \multicolumn{3}{|c|}{ Delayed maturer } \\
\hline & & $\begin{array}{l}\text { Lower } \\
\text { bound }\end{array}$ & $\begin{array}{l}\text { Upper } \\
\text { bound }\end{array}$ & $\begin{array}{c}\text { Mean IGF-1 } \\
(\mathrm{ng} / \mathrm{ml})\end{array}$ & $\begin{array}{l}\text { Mean height } \\
\text { (in.) }\end{array}$ & $\begin{array}{l}\text { Mean weight } \\
(\mathrm{kg})\end{array}$ & $\begin{array}{l}\text { Mean IGF-1 } \\
(\mathrm{ng} / \mathrm{ml})\end{array}$ & $\begin{array}{l}\text { Mean height } \\
\text { (in.) }\end{array}$ & $\begin{array}{l}\text { Mean weight } \\
(\mathrm{kg})\end{array}$ & $\begin{array}{c}\text { Mean IGF-1 } \\
(\mathrm{ng} / \mathrm{ml})\end{array}$ & $\begin{array}{l}\text { Mean height } \\
\text { (in.) }\end{array}$ & $\begin{array}{c}\text { Mean weight } \\
(\mathrm{kg})\end{array}$ \\
\hline \multirow[t]{3}{*}{$\mathrm{CS}-3$} & 13.4 & 13.2 & 13.7 & 317 & 61.9 & 40.2 & 288 & 61.3 & 39.8 & 339 & 61.6 & 42.1 \\
\hline & & & & $(226-372)$ & $(59-64)$ & $(36-43)$ & $(171-369)$ & $(58-62)$ & $(38-42)$ & (253-389) & $(59-65)$ & (39-46) \\
\hline & & & & \multicolumn{3}{|c|}{ (<13.2 years) } & \multicolumn{3}{|c|}{ (13.2-13.7 years) } & \multicolumn{3}{|c|}{ (>13.7 years) } \\
\hline \multirow[t]{3}{*}{ CS-4 } & 15.9 & 15.6 & 16.2 & 381 & 65.2 & 42.4 & 318 & 65.2 & 42.8 & 352 & 66.3 & 48.2 \\
\hline & & & & $(300-525)$ & $(62-68)$ & $(38-46)$ & $(252-398)$ & $(58-71)$ & $(37-52)$ & $(275-427)$ & $(64-68)$ & $(42-50)$ \\
\hline & & & & \multicolumn{3}{|c|}{ ( $<15.6$ years $)$} & \multicolumn{3}{|c|}{ (15.6-16.2 years) } & \multicolumn{3}{|c|}{ (>16.2 years) } \\
\hline \multirow[t]{3}{*}{ CS-5 } & 17.3 & 17.0 & 17.5 & 293 & 67.6 & 51.1 & 278 & 68.0 & 57.1 & 267 & 67.5 & 52.6 \\
\hline & & & & $(222-372)$ & $(66-68)$ & $(45-56.5)$ & $(206-311)$ & $(65-70)$ & $(52-64)$ & $(241-304)$ & $(67-68)$ & $(48-60)$ \\
\hline & & & & \multicolumn{3}{|c|}{ ( $<17.0$ years $)$} & \multicolumn{3}{|c|}{ (17.0-17.5 years) } & \multicolumn{3}{|c|}{ (>17.5 years) } \\
\hline
\end{tabular}

Advance maturers, subjects with age less than the lower bound age limit in each cervical stage. Average maturers, subjects with age within the upper and lower bound age limit in each cervical stage. Delayed maturers, subjects with age above the upper bound age limit in each cervical stage. 
Table 4 Mean IGF-1 level ( $\mathrm{ng} / \mathrm{ml}$ ) with respect to orthopedic and orthodontic treatment class

\begin{tabular}{|c|c|c|c|c|c|c|c|}
\hline \multirow[t]{2}{*}{ Group } & \multirow[t]{2}{*}{ Subjects } & \multirow[t]{2}{*}{ Mean IGF-1 (ng/ml) } & \multirow[t]{2}{*}{ SD } & \multirow[t]{2}{*}{ Median } & \multicolumn{2}{|c|}{$\mathbf{9 5} \%$ confidence interval for mean } & \multirow[t]{2}{*}{$p$ value } \\
\hline & & & & & Lower bound & Upper bound & \\
\hline Class 1 & 30 & 335 & 12.6 & 333 & 310 & 360 & 0.006 \\
\hline Class 2 & 15 & 280 & 10.8 & 285 & 258 & 302 & \\
\hline
\end{tabular}

SD, standard deviation; Class 1, orthopedic treatment class; Class 2, orthodontic treatment class.

levels in this group. The serum IGF-1 level was consistently on the lower hub in CS-5 in all three maturity groups, suggesting the fact that most patients attain their maximum growth by the time of CS-5. However, IGF-1 levels of early maturers were relatively higher than average and those of delayed type of maturers.

Another study [26] established mean serum IGF-1 levels for both sexes in all CVMI stages which were higher compared to those in our study; however, their method involved ELISA, a different technique to measure serum IGF-1 levels. The difference in mean serum IGF-1 levels may also be due to different study populations.

According to Ball et al. [11], on average, patients remain in CS-3 for 1.77 years and in CS-4 for 3.79 years. Often, we do not know at what time of the stage the cephalogram was taken, thus making it very difficult to assess the exact timing of growth spurt. The cervical vertebral maturation stages should be used along with other methods of biologic maturity assessment when considering both dentofacial orthopedic treatment and orthognathic surgery. The following combined classification may be

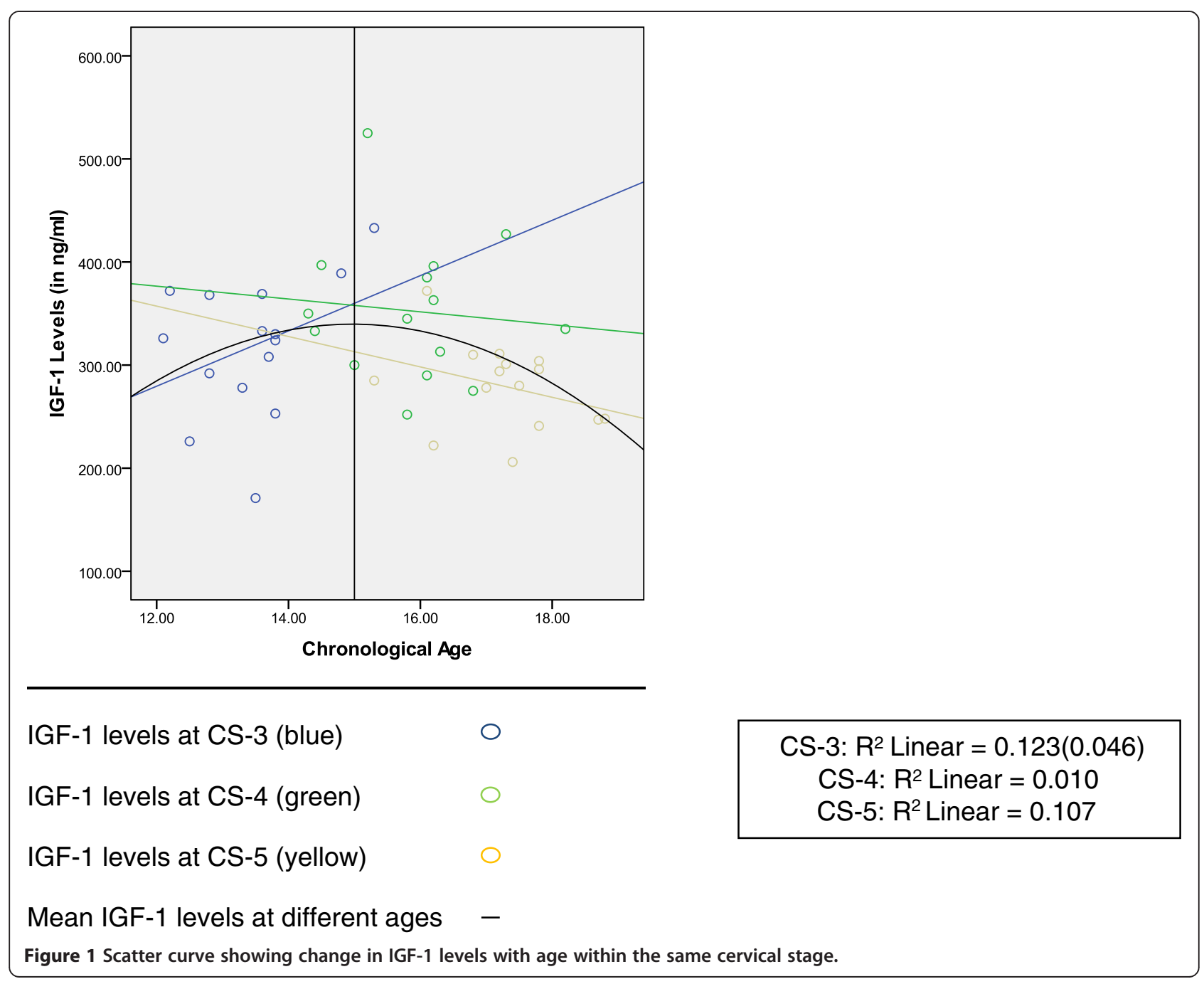


used for selection of orthopedic and orthodontic treatment groups:

Group 1: cervical stages 3 and 4 with IGF-1 levels less than $310 \mathrm{ng} / \mathrm{ml}$.

Group 2: cervical stages 3, 4, and 5 with IGF-1 levels more than $310 \mathrm{ng} / \mathrm{ml}$.

Group 3: cervical stage 5 with IGF-1 levels less than $310 \mathrm{ng} / \mathrm{ml}$.

Different clinical studies on the skeletal response of functional appliance have shown different treatment results; this may be due to the different designs of appliance, duration of treatment, patient's cooperation, type of malocclusion, and also on different maturational statuses as well as type of maturers. Hence, to reduce overall treatment timing, it would be better to follow new combined group criteria on the basis of cervical staging and quantitative assessment of IGF-1 levels. A patient showing CS-3 with serum IGF-1 levels less than $310 \mathrm{ng} / \mathrm{ml}$ can wait for IGF-1 level reevaluation to start treatment with functional appliance.

If a patient is at cervical stage 3,4 , or even 5 and has a serum IGF-1 level more than $310 \mathrm{ng} / \mathrm{ml}$, treatment for functional jaw orthopedics can be chosen. If IGF-1 level is $>310 \mathrm{ng} / \mathrm{ml}$ and cervical stage is 5 , orthopedic treatment may be started without delay because very little time for growth is remaining. Since IGF-1 levels vary as per body type (athletic, aesthetic, and plethoric) and type of maturers (early, average, and late), longitudinal study with larger sample size consisting of similar body type and type of maturer might result in establishing a clinically useful reference range.

\section{Conclusions}

Serum IGF-1 levels may be used as an additional tool for optimizing orthodontic treatment timing. Further studies with larger sample size are required to prove this.

\section{Competing interests}

The authors declare that they have no competing interests.

\section{Authors' contributions}

SJ participated in the sample collection, carried out the determination of serum IGF-1 levels by immunoassay procedure and cervical maturation stage, and prepared the manuscript. SJ designed the study and edited and reviewed the manuscript. AD carried out the literature search and participated in the data acquisition. SP carried out the statistical analysis. All authors read and approved the final manuscript.

\section{Author details}

'Department of Orthodontics \& Dentofacial Orthopedics, Government College of Dentistry, Opp. Maharaja Yashwantrao Hospital, Indore, India. ${ }^{2}$ IARI-regional section, Indore, India.

Received: 17 June 2013 Accepted: 2 October 2013

Published: 14 November 2013

\section{References}

1. Lamparski DG. Skeletal age assessment utilizing cervical vertebrae, [M.S. thesis]. University of Pittsburgh; 1972.

2. O'Reilly MT, Yanniello GJ. Mandibular growth changes and maturation of cervical vertebrae: a longitudinal cephalometric study. Angle Orthod. 1988; 58:179-84.

3. Hassel B, Farman AG. Skeletal maturation evaluation using cervical vertebrae. Am J Orthod Dentofacial Orthop. 1995; 107:58-61.

4. Franchi L, Baccetti T, McNamara JA Jr. Mandibular growth as related to cervical vertebral maturation and body height. Am J Orthod Dentofacial Orthod. 2000; 118:335-40.

5. Baccetti T, Franchi L, Toth LR, McNamara JA. An improved version of the cervical vertebral maturation (CVM) method for the assessment of mandibular growth. Angle Orthod. 2002; 72:316-23.

6. Baccetti T, Franchi L, McNamara JA. The cervical vertebral maturation (CVM) method for the assessment of optimal treatment timing in dentofacial orthopedics. Semin Orthod. 2005; 11:119-29.

7. Mito T, Sato K, Mitani H. Cervical vertebral bone age in girls. Am J Orthod Dentofacial Orthop. 2002; 122:380-5.

8. Mito T, Sato K, Mitani H. Predicting mandibular growth potential with cervical vertebral bone age. Am J Orthod Dentofacial Orthop. 2003; 124:173-7.

9. Abdel-Kader HM. The reliability of dental $x$-ray film in assessment of MP3 stages of pubertal growth spurt. Am J Orthod Dentofacial Orthop. 1998; 114:427-9.

10. Ozer T, Kama JD, Ozer SY. A practical method for determining pubertal growth spurt. Am J Orthod Dentofacial Orthop. 2006; 131:e1-6.

11. Ball G, Woodside D, Tompson B, Hunter S. Relationship between cervical vertebral maturation and mandibular growth. Am J Orthod Dentofacial Orthop. 2011; 139:e455-61.

12. Zhao X, Lin J, Jiang J, Wang Q, Hong S. Validity and reliability of a method for assessment of cervical vertebral maturation. Angle Orthod. 2012; 82:229-34.

13. Perinetti G, Baccetti T, Contardo L, Di Lenarda R. Gingival crevicular fluid alkaline phosphatase activity as a non-invasive biomarker of skeletal maturation. Orthod Craniofac Res. 2011; 14:44-50.

14. VanWyk JJ, Underwood LE, Hintz RL, Clemmons DR, Voina SJ, Weaver RP. The somatomedins: a family of insulin-like growth factor hormones under growth hormone control. Recent Prog Horm Res. 1974; 30:256-318.

15. Russell SM, Spencer EM. Local injection of human or rat growth hormone or of purified human somatomedin-C stimulate unilateral tibial epiphyseal growth in hypophysectomized rats. Endocrinology. 1985; 116:2563-7.

16. Yakar S, Rosen CJ, Beamer WG, Ackert-Bicknell CL, Wu Y, Liu JL, Ooi GT, Setser J, Frystyk J, Boisclair YR, LeRoith D. Circulating levels of IGF-1 directly regulate bone growth and density. J Clin Invest. 2002; 110:771-81.

17. Juul A, Bang P, Hertel NT, Main K, Dalgaard P, Jorgensen K, Müller J, Hall K, Skakkebaek NE. Serum insulin-like growth factor-I in 1030 healthy children, adolescents, and adults: relation to age, sex, stage of puberty, testicular size, and body mass index. J Clin Endocrinol Metab. 1994; 78:744-52.

18. Delatte M, Vonder Hoff JW, Maltha JC, Kuijpers Jaghman AM. Growth stimulation of mandibular condyles and femoral heads of newborn rats by IGF-1. Arch Oral Biol. 2004; 49:165-75.

19. Masoud M, Masoud I, Kent RL Jr, Nour G, Hassan AH, Cohen LE. Relationship between blood spot insulin like growth factor-1 levels and hand-wrist assessment of skeletal maturity. Am J Orthod Dentofacial Orthop. 2009; 136:59-64.

20. Masoud M, Masoud I, Kent RL Jr, Nour G. Assessment skeletal maturity by using blood spot insulin like growth factor I (IGF-I) testing. Am J Orthod Dentofacial Orthop. 2008; 134:209-16.

21. Brabant G, Muhlen AV, Wuster C. Serum insulin-like growth factor I reference values for an automated chemiluminescence immunoassay system: results from a multicenter study. Horm Res. 2003; 60:53-60.

22. Chertkow S. Tooth mineralization as an indicator of the pubertal growth spurt. Am J Orthod Dentofacial Orthop. 1980; 77:79-91.

23. Fishman LS. Chronological versus skeletal age, an evaluation of craniofacial growth. Angle Orthod. 1979; 49:181-9.

24. Demirjian A, Buschang PH, Tanguay R, Patterson DK. Interrelationships among measure of somatic, skeletal, dental, and sexual maturity. Am J Orthod. 1985; 88:433-8. 
25. Argente J, Barrios V, Pozo J, Munoz M, Hervas F, Stene M, Hernandez M. Normative data for IGFs, IGF-bonding proteins, and growth hormone binding protein. J Clin Endocrinol Metab. 1993; 77:1522-8.

26. Ishaq RAR, Soliman SAZ, Foda MY, Fayed MMS. Insulin-like growth factor-1: biologic maturation indicator. Am J Orthod Dentofacial Orthop. 2012; 142:654-61.

27. Jaqueira LMF, Armond MC, Pereira L, Alcantara CEP, Marques LS. Determining skeletal maturation stage using cervical vertebrae: evaluation of three diagnostic methods. Braz Oral Res. 2010; 24(4):433-7.

28. Gupta S, Jain S, Gupta P. Determining skeletal maturation using IGF-1 test. Prog Orthod. 2012; 13(3):288-95.

29. Proffit WR, Fields HW, Sarver DM. Contemporary Orthodontics. St. Louis: Mosby; 2007.

doi:10.1186/2196-1042-14-46

Cite this article as: Jain et al: Serum IGF-1 levels as a clinical tool for optimizing orthodontic treatment timing. Progress in Orthodontics 2013 14:46.

\section{Submit your manuscript to a SpringerOpen ${ }^{\circ}$ journal and benefit from:}

- Convenient online submission

- Rigorous peer review

- Immediate publication on acceptance

- Open access: articles freely available online

- High visibility within the field

- Retaining the copyright to your article 